\title{
FRANK MORTON CARPENTER (1902-1994): ACADEMIC BIOGRAPHY AND LIST OF PUBLICATIONS
}

\author{
BY DAVID G. FURTH ${ }^{1}$ \\ 18 Hamilton Rd., Arlington, MA 02174
}

The present paper is meant to accompany the preceding one by Elizabeth Brosius, Assistant Editor at the University of Kansas, Paleontological Institute, who was extremely instrumental in aiding Prof. Frank Carpenter to finish his Treatise on Invertebrate Paleontology volumes on fossil insects. The Brosius paper is a brief profile taken from her personal interaction with Prof. Carpenter as well as numerous interviews about him with his friends, students, and colleagues. The present paper is intended to be more of an account of Prof. Carpenter's academic background and accomplishments with the addition of some personal and academic accounts of the author's interaction with Frank Carpenter.

Frank Morton Carpenter was born in Boston on 6 September 1902. When he was three years old his family (father Edwin A. and mother Maude Wall) moved from Boston to Revere and at age six his family moved to Melrose where he began to attend Lincoln School the following year. His father worked for the American Express Company but had a strong interest in natural history and taught his elder son (Edwin, four years older than Frank) about the constellations. Edwin later graduated from Harvard, studied astronomy, and became Director of the Astronomical Laboratory at the University of Arizona in Tucson. When Frank Carpenter was a sixth grader at Lincoln School his father encouraged his interest in butterflies and moths. In ninth grade Frank Carpenter began taking out books about insects from the Melrose Public Library. The preceding paper by Brosius relates the story about his early stimulation concerning fossil insects and his first meeting of the Cambridge Entomological Club. Frank Carpenter began Harvard University as a Freshman in 1922 and graduated with an A.B. magna cum laude in 1926 and as a member of Phi Beta Kappa. He

Manuscript received 15 April 1994.

${ }^{1}$ New address: Department of Entomology, Smithsonian Institution, Washington, D. C. 20560. 
immediately began a graduate program under the direction of Prof. William Morton Wheeler, receiving a masters degree (S.M.) in 1927 and a D.Sc. in 1929. His graduate thesis concerned the fossil ants of North America and was published as a Bulletin of the Museum of Comparative Zoology (MCZ) in 1930 (see list below).

Frank Carpenter's professional career at Harvard University began by his being appointed as a Research Fellow in Applied Biology (1928), supported by a three year National Research Council postdoctoral grant, and continued with the following appointments: Associate in Entomology, MCZ (1931); Assistant Curator of Invertebrate Palaeontology, MCZ (1932); Instructor in Zoology (1935); Curator of Fossil Insects, MCZ (1936); Assistant Professor of Palaeontology, MCZ (1936); Associate Professor of Entomology, MCZ (1939); Member of the Board of Freshman Advisers (1942-1946, 1963-1965); Alexander Agassiz Professor of Zoology (1945) [four appointments for five years each and a final one for four years, all consecutively, 1950, 1955, 1960, 1965] ${ }^{1}$; Acting Associate Dean of the Graduate School of Arts and Sciences (1946); Acting Director of University Extension (1954, 1958, 1964-1966); Chairman of the Evolutionary Biology Training Grant Committee (1965-1973); Fisher Professor of Natural History (1969) and Emeritus (1973); President of Phi Beta Kappa (1970-1971); Alexander Agassiz Professor of Zoology Emeritus (1973); Honorary Curator of Fossil Insects, MCZ (1973).

The fossil insect collections at Harvard's MCZ are second in importance only to those at the Institute of Palaeontology of the Russian Academy of Science (Moscow). This excellence was due to Frank Carpenter, the only curator of these collections, including during the last 20 years of his life as (voluntary) Honorary Curator. Frank had a very good relationship with his Russian colleagues and, through collaboration and two visits to Moscow, he amassed a superb library of Russian paleoentomology literature.

For almost 40 years Frank Carpenter taught entomology, paleontology, and related subjects at Harvard. He never took a sabbatical! His famous year-long course in entomology stimulated many students, a number of whom went on to become professional ento-

\footnotetext{
1 According to Frank Carpenter, the Agassiz family bequest stated that if someone was appointed to an Agassiz Professorship for five consecutive terms of five years each, then that person was entitled to receive a salary for life.
} 
mologists. As Edward O. Wilson wrote (1976, J. Paleontology 50(3):549-550), Frank Carpenter was the "embodiment of entomology at Harvard" and played a "role as paterfamilias of the Harvard entomological community." Carpenter was chairman of the Department of Biology from 1952-1959, an important period of biological development at Harvard. Frank Carpenter was also a devoted teacher at the Harvard Extension School for more than 30 years, longer than any other professor, and besides being Acting Director several times, he was renowned for stimulating the interest of many students in insects and he considered this a very fulfilling experience.

Frank Carpenter's influence in evolutionary biology was also recognized outside Harvard. During, and even after, his official academic career at Harvard he was awarded a number of research grants, especially from the National Science Foundation. He was a Fellow of the American Academy of Arts and Sciences and its Vice President from 1961 to 1963 and President of the National Scientific Research Society (Sigma Xi) from 1955 to 1957. In 1975 he was awarded the Paleontology Society Medal and in 1983 was elected an Honorary Fellow of the Royal Entomological Society. Finally, in 1993 he received the Thomas Say Award from the Entomological Society of America (Fig. 1).

As Robin Wootton, a close colleague of Frank Carpenter's, described him (1994, Antenna 18(2):56-58): "Simply, he was the greatest ever palaeoentomologist." Carpenter conducted research on fossil insects for almost 70 years, specializing in insects from the Paleozoic Era, an especially significant time, when many entire orders and families were completely different from the modern ones, unlike the Mesozoic. Carpenter particularly concentrated on the Permian and Carboniferous, publishing numerous papers on the Lower Permian fauna of Elmo, Kansas; the Lower Permian of Midco, Oklahoma; and the Carboniferous of North America (especially Mazon Creek, Illinois). However, he also published important works on other periods, e.g., Miocene shales of Florissant, Colorado and studies of amber from the Tertiary Baltic and Cretaceous Canadian deposits. Carpenter described one of the most famous fossil insects, a dragonfly from Elmo, with a wingspan of about 29 inches, Meganeuropsis americana Carpenter 1947, the largest insect ever known (Fig. 2). 


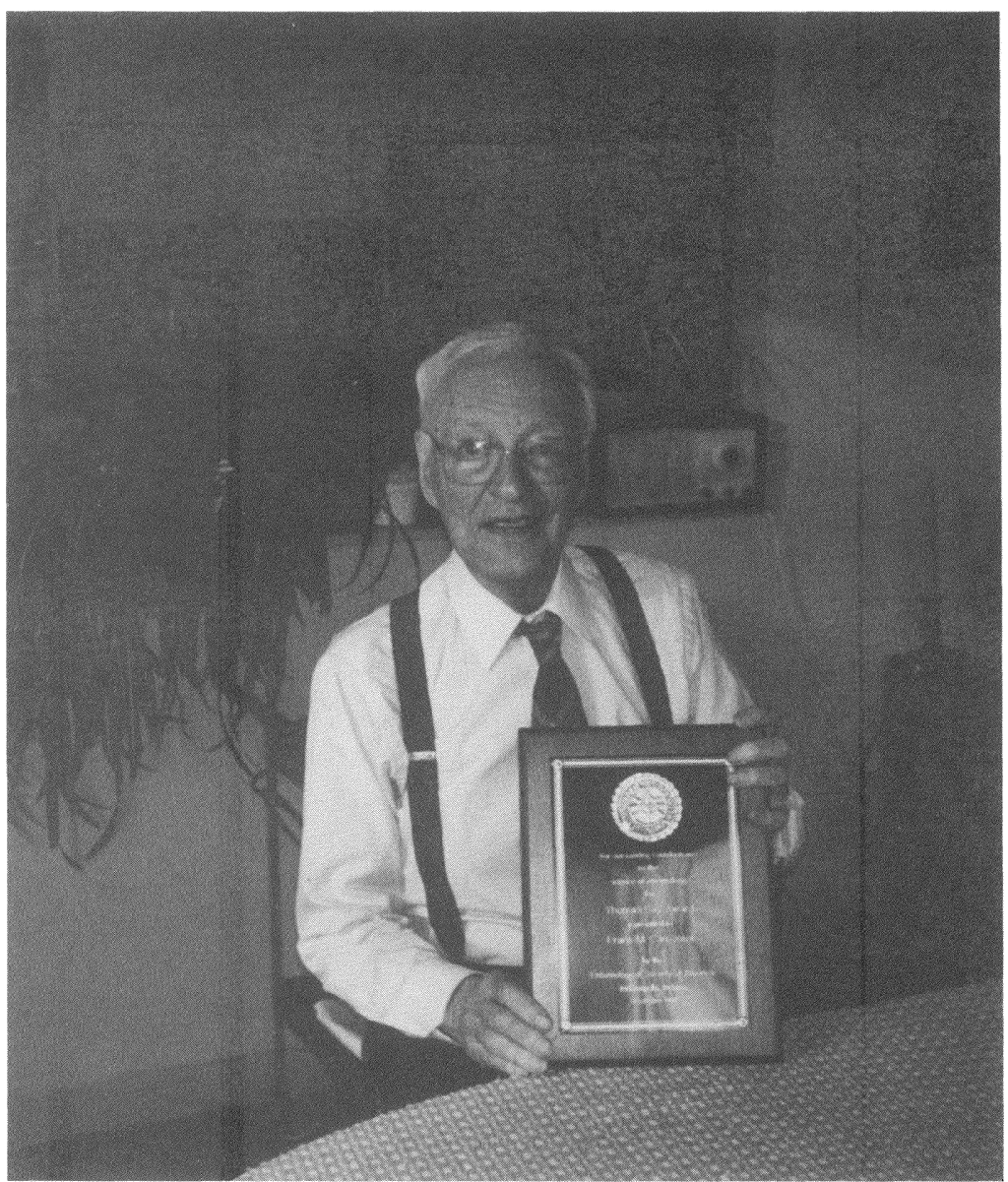

Fig. 1. Prof. Frank M. Carpenter holding the Thomas Say Award, from the Entomological Society of America awarded in December 1993. This photo taken at his home was the last photo of Prof. Carpenter. (photo 28 December 1993, by David G. Furth)

Carpenter also produced many papers on extant insects, particularly Neuroptera, Raphidiodea and Mecoptera. One of his best known entomological contributions was as coauthor of the Classifcation of Insects (1954) with C. T. Brues and A. L. Melander. This book was one of the first to offer keys and literature for all extant 


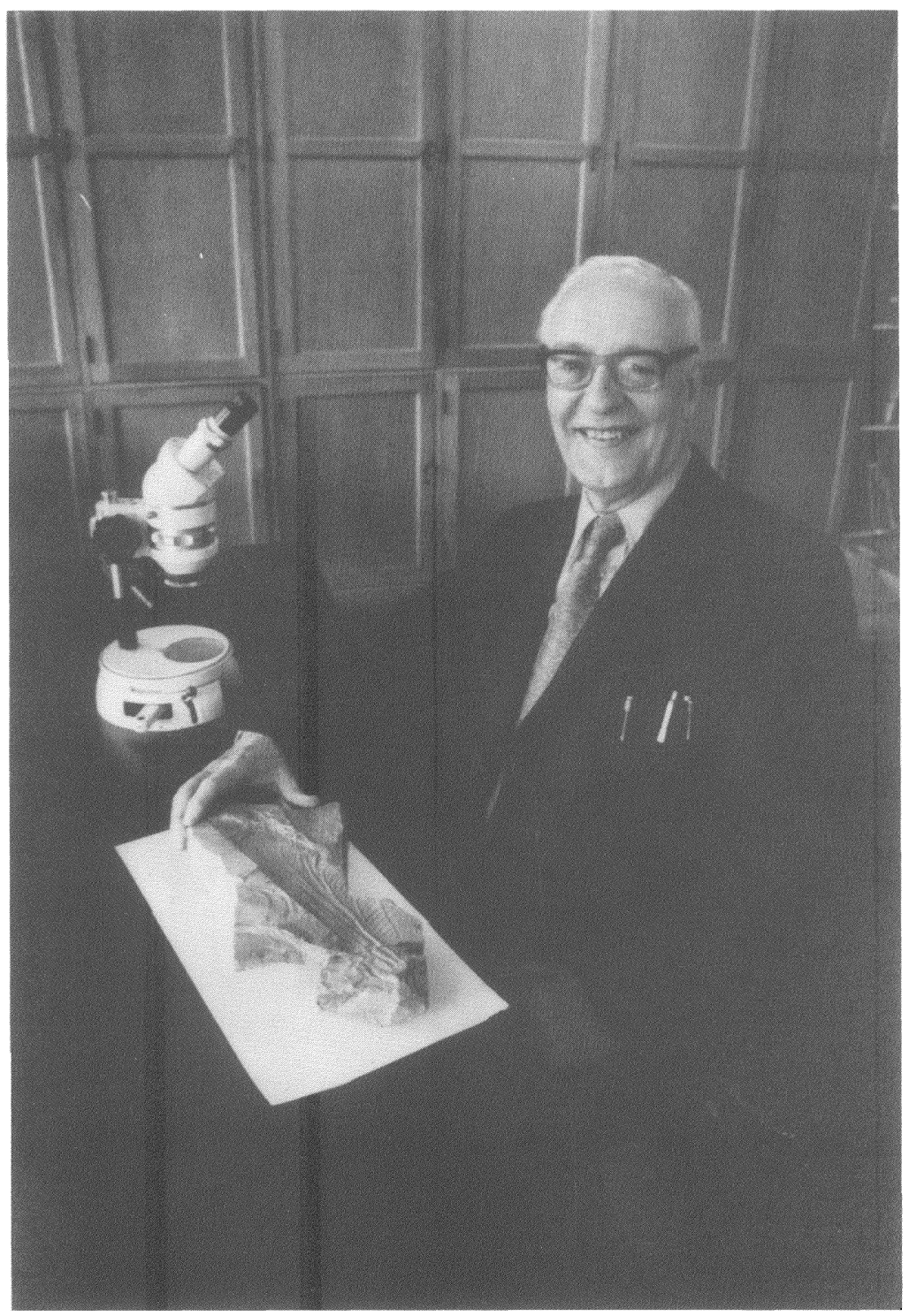

Fig. 2. Prof. Frank M. Carpenter with the fossil dragonfly Meganeuropsis americana Carpenter, the largest known insect. (photo taken at about the time of his retirement in 1973, photographer unknown to author) 
insect families (and often subfamilies) worldwide, and it also contained sections on other terrestrial arthropods and extinct insects.

After his retirement in 1973, Frank Carpenter concentrated on completing the Treatise of fossil insects, while continuing to voluntarily care for the MCZ fossil insect collection, editing Psyche, and coordinating the smooth progress of the Cambridge Entomological Club (he was still its Treasurer, parliamentarian, and father figure). In these efforts he was tirelessly assisted by his devoted wife of 62 years, Ruth Skace Carpenter (Fig. 3).

Frank Carpenter was certainly the most important person in the history of the Cambridge Entomological Club. This society and its journal (Psyche), founded in 1874, are the second oldest entomological society and journal in the United States; only the American Entomological Society (Entomological Society of Philadelphia), founded in 1859, and its journal (Transactions started in 1866) are older. Frank Carpenter held the following positions in the Cambridge Entomological Club: Secretary (1927); Associate Editor (1927-1946); Vice President (1928, 1936, 1939); President (1929, 1930, 1940); Treasurer (1944-1989); Editor (1947-1990). As both Treasurer for 46 years and Associate Editor and Editor for 64 years, Frank Carpenter basically was the Cambridge Entomological Club for almost five decades. It is unlikely that anyone will ever be of equal importance to this society. In addition, Carpenter gave over 50 presentations at regular meetings of the Club. Frank Carpenter became a formal member of the Club during his Freshman year at Harvard (1922); however, he began attending meetings several years earlier while still in high school. In honor of his 70 years of membership, the 1991-1992 Club program of monthly speakers was dedicated to Frank Carpenter, and the final issue of volume 99 of Psyche was dedicated to him.

I met Frank Carpenter during the summer of 1971 while I was a graduate student in entomology at Cornell University. At Cornell Prof. William L. Brown, Jr. (a former student of Carpenter's) and I had struggled to determine a brachypterous brown lacewing, Psectra diptera (Burmeister) (Hemerobiidae), which I had collected years earlier at one of my favorite childhood collecting sites in Ohio. Brown advised me to show the specimen to Frank Carpenter at Harvard, which I did. Not only did I learn that this specimen represented a quite rare species, but, like so many others before 


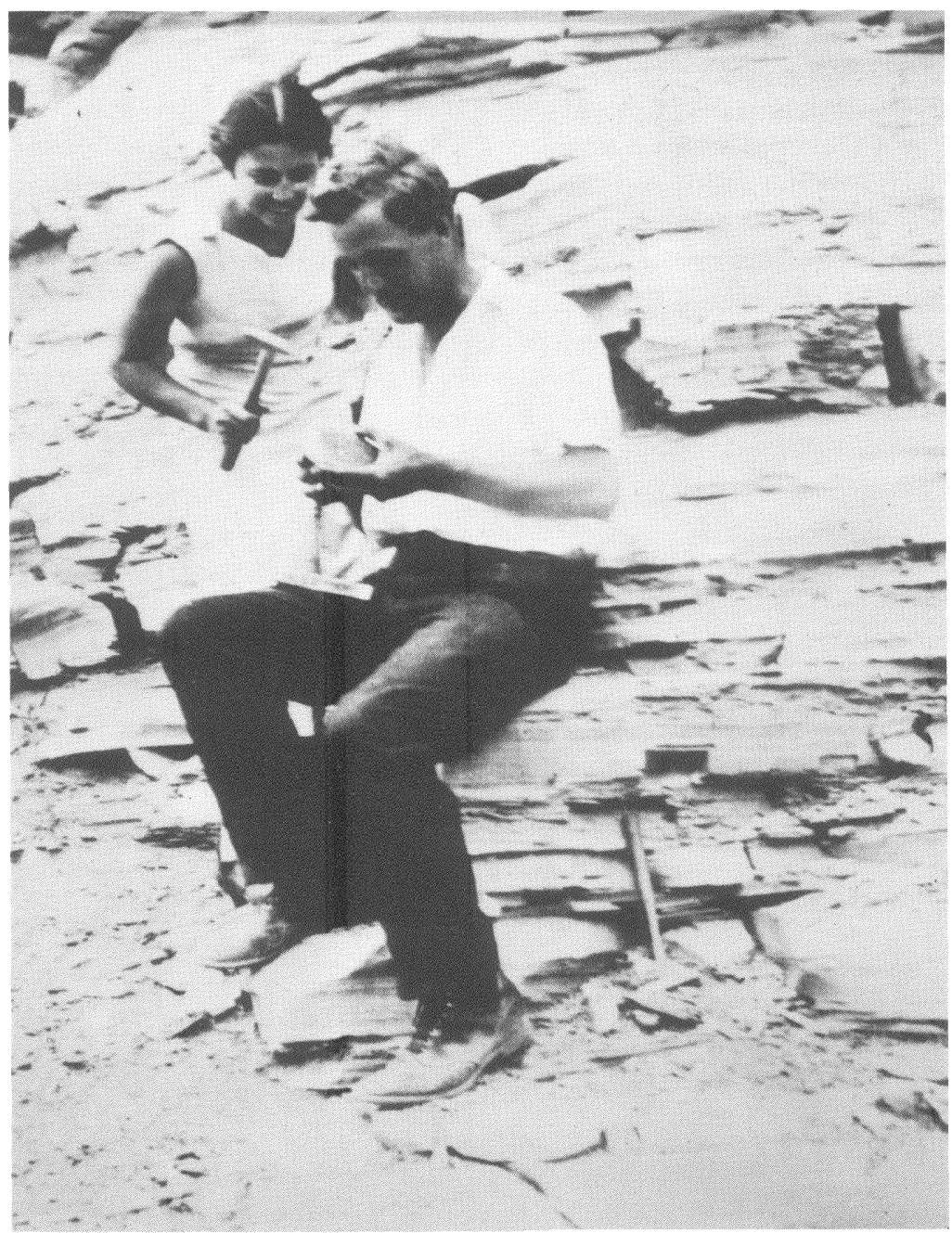

Fig. 3. Prof. Frank M. Carpenter and his wife Ruth searching for fossils in the Eocene Green River shales at Watson, Utah, July 1935. 
and after, I was impressed with his graciousness-he was the definition of a perfect gentleman; that is, polite, gracious, modest, generous, and always well dressed.

I had the privilege of becoming a close colleague as well as personal friend of Frank Carpenter during his final years, taking over from him the editorship of Psyche and many of the responsibilities of the Cambridge Entomological Club. Frank told me many interesting stories about Harvard, the MCZ and its former directors, colleagues, students, and events. After hearing many of Frank's colleagues, students, and friends reminisce about the wonderful stories he told at his famous weekly teas, I decided to tape-record (audio) Frank telling these stories. These tapes have been deposited at the Harvard University Archives. It was a great honor and thrill for me to have been close with so great an entomologist as Frank Carpenter.

In his home town of Lexington, Massachusetts, on 18 January 1994, in his 92nd year, Frank Morton Carpenter became extinct. With this loss, the Department of Entomology at the MCZ of Harvard University and the world of entomology and paleontology will never be the same. 


\section{LIST OF PUBLICATIONS BY F.M. CARPENTER}

1926

Fossil insects from the Lower Permian of Kansas. Bull. Mus. Comp. Zool. 67(13):437-444, pl.1-3.

1927

Notes on a collection of amber ants. Psyche 34(1):30-32.

A fossil insect from the Lower Permian of the Grand Canyon. Proc. U. S. Nat. Mus. $71: 1-4, \mathrm{pl} .1$.

1928

A new Protodonatan from the Grand Canyon. Psyche 35(3):187-190, pl.5.

A Scorpion-fly from the Green River Eocene. Ann. Carnegie Mus. 28:241-249, 1 fig., pl.12.

1929

A Jurassic neuropteron from the lithographic limestone of Bavaria. Psyche 36(3): 190-194, 1 fig.

1930

A fossil ant from the Lower Eocene (Wilcox) of Tennessee. J. Wash. Acad. Sci. 19(14):300-301, 1 fig.

The fossil ants of North America. Bull. Mus. Comp. Zool. 70(1):3-66, pl. 1-11.

The Lower Permian insects of Kansas. Part I. Introduction and the order Mecoptera. Bull. Mus. Comp. Zool. 70(2):69-101, 3 figs., pl.1-5.

A review of our present knowledge of the geological history of the insects. Psyche 37(1):15-34, 3 tables.

Um Blattide Permiano do Brasil. Bol. Serv. Geol. Mineralog. Brasil 50:4-11, 1 fig.

The interpretation of the wing venation and tracheation of the Odonata and Agnatha (by A.V. Martynov). [English translation from the Russian.] Psyche 37(3): 245-280.

1931

The Lower Permian insects of Kansas. Part 2. The orders Paleodictyoptera, Protodonata, and Odonata. Amer. J. Sci. (Series 5) 21(122):97-139, 6 figs.

The Lower Permian insects of Kansas. Part 3. The Protohymenoptera. Psyche 37(4): 343-374, 4 figs., pl.15-17. (1930)

The biology of the Mecoptera. Psyche 38(1):41-55, 1 fig.

The Lower Permian insects of Kansas. Part 4. The order Hemiptera, and additions to the Paleodictyoptera and Protohymenoptera. Amer J. Sci. (Series 5) 22(128): $113-130,8$ figs. 
The affinities of Holcorpa maculosa Scudder and other Tertiary Mecoptera, with descriptions of new genera. J. N. Y. Ent. Soc. 39(3):405-414, 2 figs., pl.33.

Insects from the Miocene (Latah) of Washington: I. Introduction, VI. Trichoptera. Ann. Ent. Soc. Amer. 24(2):307-309, 319-322, 3 figs.,

[entire paper, 24(2): 307-323; 5 figs., pl.1; with T. D. A. Cockerell, C. H. Kennedy, T. E. Snyder, and H. F. Wickham]

Revision of the Nearctic Mecoptera. Bull. Mus. Comp. Zool. 72(6):205-277, 6 figs., pl.1-8.

Evolution of insects. Evolution 3(2):4-5, 4 figs.

Evolution of the Class Insecta. Amer. J. Sci. 21(126):531-539.

[with P. E. Raymond and A. Petrunkevitch]

Neopanorpa hirsuta (Crampton). Psyche 38(4):184-185, 1 fig.

Jurassic insects from Solenhofen in the Carnegie Museum and the Museum of Comparative Zoology. Ann. Carnegie Mus. 21(3):97-129, 11 figs.

The Lower Permian insects of Kansas. Part 5. Psocoptera and additions to the Homoptera. Amer. J. Sci. (Series 5) 24(139):1-22, 11 figs.

Additional notes on Nearctic Mecoptera. Bull. Brooklyn Ent. Soc. 27(3):149-151.

1933

A new Boreus from British Columbia (Mecoptera). Can. Ent. 65(4):94-95, 1 fig.

Note on Haplodictyus incertus Navas. Psyche 39(4):144. (1932)

Trichoptera from the mountains of North Carolina and Tennessee. Psyche 40(1): 32-47, 1 fig., pl.1-2.

The Lower Permian insects of Kansas. Part 6. Delopteridae, Protelytroptera, Plectoptera and a new collection of Protodonata, Odonata, Megasecoptera, Homoptera, and Psocoptera. Proc. Amer. Acad. Arts Sci. 68(11):411-503, 29 figs., pl.1.

A new Megasecopteran from the Carboniferous of Kansas. Univ. Kans. Sci. Bull. 21(10):365-367, 1 fig.

\section{4}

Carboniferous insects from Pennsylvania in the Carnegie Museum and the Museum of Comparative Zoology. Ann. Carnegie Mus. 22(3-4):323-341, 13 figs., pl.24.

1935

Tertiary insects of the family Chrysopidae. J. Palaeont. 9(3):259-271, 9 figs.

A new name for Lithomyrmex Carp. (Hymenoptera). Psyche 42(2):91.

New Nearctic Mecoptera, with notes on other species. Psyche 42(2):105-122, pl.10-11.

Fossil insects in Canadian Amber. Univ. Toronto Studies, Geol. Ser. 38:69. 
The Lower Permian insects of Kansas. Part 7. The order Protoperlaria. Proc. Amer. Acad. Arts. Sci. 70(4):103-146, 11 figs, pl.1-2.

1936

Revision of the Nearctic Raphidiodea (recent and fossil). Proc. Amer. Acad. Arts Sci. 71(2):89-157, 13 figs., pl.1-2.

The Nemestrinidae of the Miocene of Florissant, Colorado, and their relations to the recent fauna. J. Palaeont. 10(5):395-409, 7 figs.

Descriptions and records of Nearctic Mecoptera. Psyche 43(2-3):56-64, 3 figs.

Collecting fossil insects. Harvard Alum. Bull. 39(19):588-591, 4 figs.

William Morton Wheeler. Science 85(2214):533-535.

[third author with L. J. Henderson, T. Barbour, H. Zinsser]

William Morton Wheeler. Bull. N. England Mus. Nat. Hist. 84:3-8, 1 fig. [third author with L. J. Henderson, T. Barbour, H. Zinsser]

Early views of fossils. Evolution 4(1):13, 2 figs.

Book Review: A monograph of the British Neuroptera, Vol. 1, by F.J. Killington. Psyche 44(1-2):59.

Insects and arachnids from Canadian Amber. Univ. Toronto Studies, Geol. Ser. Introduction. 40:7-13

[entire paper, 40:7-62, 12 figs.; with J. W. Folsom, E. O. Essig, A. C. Kinsey, C. T. Brues, M. W. Boesel, and H. E. Ewing]

A Permian insect from Coahuila, Mexico. Amer. J. Sci. 34(200):125-127, 1 fig. [with A. K. Miller]

William Morton Wheeler. Ann. Ent. Soc. Amer. 30(3):433-437, 1 fig. [second author with A. L. Melander]

1938

The structure of Permian Homoptera and Psocoptera. Nature 141:164-165.

Discussions and Communications: "Neue Untersuchungen über die fossilen Insekten mit Ergänzungen und Nachträgen sowie Ausblicken auf phylogenetische palaeogeographische und allgemein biologische Probleme". Anton Handlirsch. Ann. Naturhist. Mus. Wien, Bd. 48, pp. 1-140, 1937. Amer. J. Sci. 35:308-309.

Andreas Vassilievitch Martynov. Psyche 45(1):80-83, pl.12.

William Morton Wheeler. Isis 28(2):420-423, pl.9.

Fossil insects from the Creede Formation, Colorado. Part 1. Introduction, Neuroptera, Isoptera and Diptera. Psyche 54(2-3):105-119, 3 figs., pl.13.

[with T. E. Snyder, C. P. Alexander, M. T. James and F. M. Hull]

Two Carboniferous insects from the vicinity of Mazon Creek, Illinois. Amer. J. Sci. (Series 5) 36(216):445-452, 3 figs.

Mecoptera from China, with descriptions of new species. Proc. Ent. Soc. Wash. 40(9):267-281, pl.23-24. 
The Lower Permian insects of Kansas. Part 8. Additional Megasecoptera, Protodonata, Odonata, Homoptera, Psocoptera, Protelytroptera, Plectoptera, and Protoperlaria. Proc. Amer. Acad. Arts Sci. 73(3):29-70, 27 figs., pl.1-2.

Records and notes of Nearctic Mecoptera and Raphidiodea. Bull. Brooklyn Ent. Soc. 34(3):162-166, 1 fig.

\section{0}

The fossil Pipunculidae. Bernstein-Forschungen 4:8-17, 9 figs. [with F. M. Hull] (1939)

Carboniferous insects from the Stanton Formation, Kansas. Amer. J. Sci. (Series 5) 238(9):636-642, 1 fig., pl.1.

Book Review: A laboratory guide to the study of the evolution of the wings of insects, by J. Chester Bradley. 2nd ed. Ithaca, N.Y. Psyche 47(1):44.

A revision of the Nearctic Hemerobiidae, Berothidae, Sisyridae, Polystoechotidae and Dilaridae (Neuroptera). Proc. Amer. Acad. Arts Sci. 74(7):193-280, 75 figs., pl.1-3.

\section{1}

A new genus of Mecoptera from Tasmania. Papers Proc. Roy. Soc. Tasmania 1940:51-53, pl.7-8. (1940)

The antiquity of social insects. Psyche 48(1):50-55. [second author with J. C. Bequaert]

\section{3}

Notes on Nearctic Neuroptera. Psyche. 49(3-4):49-51, 1 fig. (1942)

Studies on Carboniferous insects from Commentry, France; Part 1. Introduction and families Protagriidae, Meganeuridae, and Campylopteridae. Bull. Geol. Soc. Amer. 54:527-554, 5 figs., pl.1.

The Lower Permian insects of Kansas. Part 9. The orders Neuroptera, Raphidiodea, Caloneurodea and Protorthoptera (Probnisidae), with additional Protodonata and Megasecoptera. Proc. Amer. Acad. Arts Sci. 75(2):55-84, 16 figs., pl.1.

Osmylidae of the Florissant Shales, Colorado (Insecta -Neuroptera). Amer. J. Sci. (Series 5) 241(12):753-760, 3 figs., pl.1.

\section{4}

Carboniferous insects from the vicinity of Mazon Creek, Illinois. Ill. State Mus. Sci. Papers 3(1):1-20, 5 figs., pl.1-4. (1943)

Class Insecta. pp. 701, 703, 2 figs. In: H. W. Shimer and R. R. Shrock (Eds.), Index fossils of North America, The M.I.T. Press, Cambridge.

1945

Panorpidae from China (Mecoptera). Psyche 52(1-2):70-78, 7 figs., pl.10-11. 
Lower Permian insects from Oklahoma. Part 1. Introduction and the orders Megasecoptera, Protodonata, and Odonata. Proc. Amer. Acad. Arts Sci. 76(2): 25-54, 28 figs., pl.1-2.

Early insect life. Psyche 54(2):65-85, 9 figs.

Taxonomic notes on the Dilaridae (Neuroptera). Psyche 54(2):100-109, 5 figs.

\section{8}

Notes on Chinese Panorpidae (Mecoptera). Psyche 55(1):28-30, 1 fig.

The supposed nymphs of the Palaeodictyoptera. Psyche 55(1):41-50, pl.6-7.

A Permian insect from Texas. Psyche 55(2):101-103, 1 fig.

\section{0}

Fossil insects. Gamma Alpha Record (Harvard Issue) 40(3):61-68, 3 figs.

The Lower Permian insects of Kansas. Part 10. The order Protorthoptera: The family Liomopteridae and its relatives. Proc. Amer. Acad. Arts Sci. 78(4):187-219, 11 figs., pl.1-3.

\section{1}

The structure and relationships of Oliarces (Neuroptera). Psyche 58(1):32-41, 3 figs., pl.4.

Studies on Carboniferous insects from Commentry, France; Part II. The Megasecoptera. J. Paleont. 25(3):336-355, 11 figs., pl.53.

Rediscription of Parapapolia superba (Scudder) (Protorthoptera). Psyche 58(3): 108-110, 1 fig.

1953

Fossil insects. Yearbook of Agric., 1952, pp. 14-19 (Sep. No. 2292), 2 figs.

The geological history and evolution of insects. Amer. Sci. 41(2):256-270, 7 figs.

The biology of Brachypanorpa (Mecoptera). Psyche 60(1):28-36, 1 fig., pl.2.

The geological history and evolution of insects. In: G. A. Baitsell (Ed.). Science in Progress. Ser. 8, Ch. 4, pp.71-89. Yale Univ. Press, New Haven.

1954

Additional notes on Brachypanorpa. Psyche 60(4):154. (1953)

Classification of insects (revised edition). Bull. Mus. Comp. Zool. 108:1-917, 1219 figs.

[third author with C. T. Brues and A. L. Melander]

The Baltic Amber Mecoptera. Psyche 61(1):31-40, 4 figs.

Nathan Banks. Harvard University Gazette, 49(17):118.

[fourth author with H. B. Bigelow, C. T. Brues, and A. S. Romer]

Nathan Banks, A biographical sketch and list of publications. Psyche 61(3):81-110, pl.5.

[with P. J. Darlington, Jr.] 
Neuroptera and Mecoptera. pp. 536-538. In: E. S. Ross (Ed.) Systematic Entomology. In: E. L. Kessel (Ed.), A Century of Progress in the Natural Sciences 1853-1953. California Academy of Sciences, San Francisco.

Fossil Insects. pp. 588-590. In: E. S. Ross (Ed.) Systematic Entomology. In: E. L. Kessel (Ed.), A Century of Progress in the Natural Sciences 1853-1953. California Academy of Sciences, San Francisco.

An Eocene Bittacus (Mecoptera). Psyche 62(1):39-41, 2 figs.

Redescription of Spiloconis picticornis Banks (Neuroptera: Coniopterygidae). Psyche 62(2):69-74, pl.7.

C. T. Brues, Zoologist. Science 122(3172):679. [second author with A. L. Melander]

Charles Thomas Brues. Harvard University Gazette 51(14):107-108. [third author with A. S. Romer and I. W. Bailey]

1957

The Baltic Amber Snake-flies (Neuroptera). Psyche 63(3):77-81, 3 figs. (1956)

\section{8}

A Pliocene insect deposit in Texas. Psyche 64(3):116. (1957)

1959

Mexican Snake-flies (Neuroptera: Raphidiodea). Psyche 65(2-3): 52-58, 3 figs., pl.7. (1958)

1960

Fossil Nemopteridae (Neuroptera). Psyche 66(1-2):20-24, 1 fig., pl.1. (1959)

1961

The female of Inocellia pilicornis Carp. (Neuroptera: Inocelliidae). Psyche 67(1-2): 41-42, 1 fig. (1960)

A Triassic odonate from Argentina. Psyche 67(3):71-75, 1 fig., pl.9. (1960)

Insects of Micronesia. Neuroptera: Hemerobiidae. Vol. 8(3):35-43, 4 figs. B. P. Bishop Museum, Honolulu.

Studies on North American Carboniferous insects. 1. The Protodonata. Psyche 67(4):98-110, 4 figs., pl.11. (1960)

1962

Book Review: Introduction to entomology, by R. Jeannel, translated by Harold Oldroyd, 1960. Amer. Sci. 50:178A, 180A.

Studies on Carboniferous insects of Commentry, France: Part III. The Caloneurodea. Psyche 68(4):145-153, 2 figs. (1961)

A Permian Megasecopteron from Texas. Psyche 69(1):37-41, 2 figs., pl.1. 
A Megasecopteron from Upper Carboniferous strata in Spain. Psyche 70(1):44-49, 1 fig., pl.4-5.

Studies on North American Carboniferous Insects. 2. The genus Brodioptera from the Maritime Provinces, Canada. Psyche 70(1):59-63, 2 figs.

Studies on Carboniferous insects from Commentry, France: Part IV. The genus Triplosoba. Psyche 70(2):120-128, pl.13-14.

Studies on Carboniferous insects of Commentry, France: Part V. The genus Diaphanoptera and the order Diaphanopterodea. Psyche 70(4):240-256, 1 fig., pl.28-30.

\section{4}

Studies on the Carboniferous insects of Commentry, France: Part VI. The genus Dictyoptilus (Palaeodictyoptera). Psyche 71(2):104-116, 1 fig., pl.13-14.

Studies on North American Carboniferous insects. 3. A spilapterid from the vicinity of Mazon Creek, Illinois (Palaeodictyoptera). Psyche 71(3):116-124, pl.15-18.

Lower Permian insect fauna from Elmo, Kansas. pp. 302-303. In: R. C. Moore, Palecological aspects of Kansas Pennsylvanian and Permian cyclothems. In: D. F. Merriam (Ed.), Symposium on cyclic sedimentation. Kansas State Geol. Surv. Bull. 169(1):1-380.

\section{5}

The structure of the Protelytroptera, with description of a new genus from Permian strata of Moravia. Psyche 71(4):183-197, 6 figs., pl.22.

[with J. Kukalova] (1964)

Studies on North American Carboniferous insects. 4. The genera Metropator, Eubleptus, Hapaloptera and Hadentomum. Psyche 72(2):175-190, 7 figs.

1966

The Lower Permian insects of Kansas. Part 11. The orders Protorthoptera and Orthoptera. Psyche 73(1):46-88, 20 figs., pl.4-7.

\section{7}

The first Mesozoic ants, with the description of a new subfamily. Psyche 74(1): 1-19, 2 tables, 4 figs., pl.1-4.

[second author with E. O. Wilson and W. L. Brown, Jr.]

Studies on North American Carboniferous insects. 5. Palaeodictyoptera and Megasecoptera from Illinois and Tennessee, with a discussion of the order Sypharopteroidea. Psyche 74(1):58-84, 5 figs., pl.8-14.

The first Mesozoic ants. Science 157(3792):1038-1040, 2 figs.. [second author with E. O. Wilson and W. L. Brown, Jr.]

\section{8}

The structure and relationships of Stephanomioptera Guthörl (Miomoptera-Palaeomanteidae). Psyche 74(3):224-227, 2 figs. (1967) 
Cretaceous Insects from Labrador. 2. A new family of Snake-flies (Neuroptera: Alloraphidiidae). Psyche 74(4):270-275, 2 figs., pl.35.

[entire paper, 74(4): 267-289, with E. Dorf and A. Emerson] (1967)

The affinities of the genus Sobobapteron Pierce. Bull. So. Calif. Acad. Sci. 67(4): 263-265, 1 fig.

Hexapoda. (p.1369) In: R.C. Moore, et al. (53 authors) "Developments, trends, and outlooks in Paleontology". J. Paleont. 42(6):1327-1377.

\section{9}

Megasecopterous nymphs in Pennsylvanian concretions from Illinois. Psyche 75(4): 295-309, 2 figs., pl.24-28.

[with E. S. Richardson, Jr.] (1968)

1970

Fossil insects from Antarctica. Psyche 76(4):418-425, 6 figs. (1969)

1971

Adaptations among Palaeozoic insects. Proc. N. Amer. Paleont. Convention 1969: 1236-1251, 19 figs.

Fossil insects from New Mexico. Psyche 77(4):400-412, 7 figs. (1970)

\section{2}

Additional insects in Pennsylvanian concretions from Illinois. Psyche 78(4): 267-295, 20 figs.

[with E. S. Richardson, Jr.] (1971)

The affinities of Eomerope and Dinopanorpa (Mecoptera). Psyche 79(1-2):79-87, 9 figs.

\section{4}

Fossiliferous Amber from the Eocene (Claiborne) of the Gulf Coastal Plain. Geol. Soc. Amer. Bull. 85:979-984, 7 figs.

[third author with W. B. Saunders, R. H. Mapes, and W. C. Elsik].

\section{6}

Note on Bittacus validus in Baltic Amber. Psyche 82(3-4):303. (1975)

Response for award of Paleontological Society Medal, October 21, 1975. J. Paleont. 50(3):551.

Geological history and evolution of the insects. Proc. XV International Congress of Entomology, Washington, D. C., August 19-27, 1976, pp. 63-70, 9 figs.

1977

Structure and relationships of the Upper Carboniferous insect, Eucaenus ovalis (Protorthoptera: Eucaenidae). Psyche 83(3-4):223-242, 8 figs.

[with E. S. Richardson, Jr.] (1976) 
The Lower Permian insects of Kansas. Part 12. Protorthoptera (continued), Neuroptera, additional Palaeodictyoptera, and families of uncertain position. Psyche 83(3-4):336-376, 23 figs. (1976)

1978

Structure and relationships of the Upper Carboniferous insect, Prochoroptera calopteryx (Diaphanopterodea, Prochoropteridae) Psyche 85(2-3):219-228, 3 figs.

[with E. S. Richardson, Jr.]

1979

Biota. age, and significance of lake deposits, Carapace Nunatak, Victoria Land, Antarctica. Proc. 4th International Gondwana Symposium: Papers (Vol. 1), Calcutta, 1977. pp. 166-175, pl.63-69.

[fifth author with H. W. Ball, H. W. Borns, Jr., B. A. Hall, H. K. Brooks, and T. Delevoryas.]

A restudy of two ants from the Sicilian Amber. Psyche 85(4):417-423, 4 figs.

[second author with W. L. Brown, Jr.) (1978)

Antiquity of social insects. In: H. R. Hermann (ed.). Social Insects, vol. 1, pp. 81-89, 2 tables, 3 figs. Academic Press Inc., N.Y., San Francisco, London.

[with H. R. Hermann]

Lower Permian insects from Oklahoma. Part 2. Orders Ephemeroptera and Palaeodictyoptera. Psyche 86(2-3):261-290, 1 table, 17 figs.

1980

Studies on North American Carboniferous insects. 6. Upper Carboniferous insects from Pennsylvania. Psyche 87(1-2):107-119, 5 figs.

1981

Typus Sellards, 1909 (Insecta, Protodonata): Proposed conservation under plenary powers. Z.N.(S.) 2359. Bull. Zool. Nom. 38(4):285-286.

[with P. Whalley]

1983

Studies on North American Carboniferous insects. 7. The structure and relationships of Eubleptus danielsi (Palaeodictyoptera). Psyche 90(1-2):81-95, 8 figs.

1985

The geological record of insects. Ann. Rev. Earth Planet. Sci. 13:297-314, 1 table, 2 figs.

[with L. Burnham]

Philip Jackson Darlington, Jr.: A biographical sketch, pp. 7-10. In: G. E. Ball (Ed.) Taxonomy, phylogeny and zoogeography of beetles and ants. Dr. W. Junk Publ., Dordrecht.

1986

Substitute names for some extinct genera of fossil insects. Psyche 92(4):575-582. (1985) 
Substitute names for the extinct genera Cycloptera Martynova (Mecoptera) and Parelcana Carpenter (Orthoptera). Psyche 93(3-4):375-376. (1986)

1988

Review of the extinct family Syntonopteridae (order uncertain). Psyche 94(3-4): 373-388, 9 figs. (1987)

1990

A Substitute Name for the Extinct genus Eoricania Haupt (Hemiptera: Homoptera: Ricaniidae). Psyche 97(1-2):131.

1991

A substitute name for the extinct genus Proberotha Riek (Neuroptera). Psyche 98(1):87.

1992

Studies of North American Carboniferous insects. 8. New Paleodictyoptera from Kansas, USA. Psyche 99(2-3):141-146, 4 figs.

Studies of North American Carboniferous insects. 9. A new species of Eubleptidae from Mazon Creek (Palaeodictyoptera). Psyche 99(2-3):147-152, 4 figs.

Treatise on invertebrate paleontology. Part R, Arthropoda 4, Vols. 3 \& 4: Superclass Hexapoda, 655 pp., 265 figs. The Geological Society of America, Inc. and The University of Kansas, Boulder and Lawrence.

Affinities of the extinct genera Chresmoda (Orthoptera) and Propygolampis (Phasmatodea). This paper was quoted in the References of Carpenter's 1992 Treatise as "Psyche 99:(in press)"; however, this manuscript was never published. 

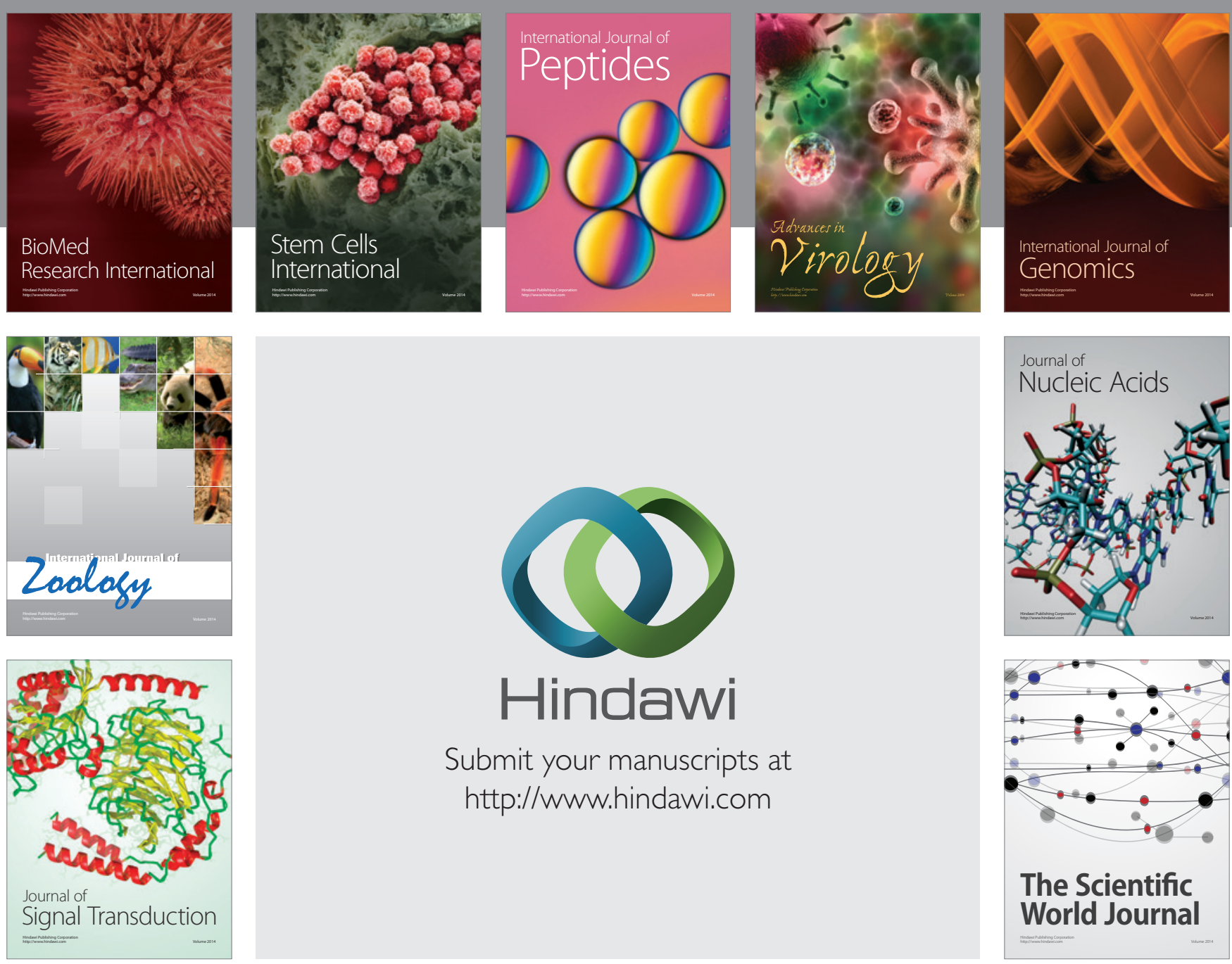

Submit your manuscripts at

http://www.hindawi.com
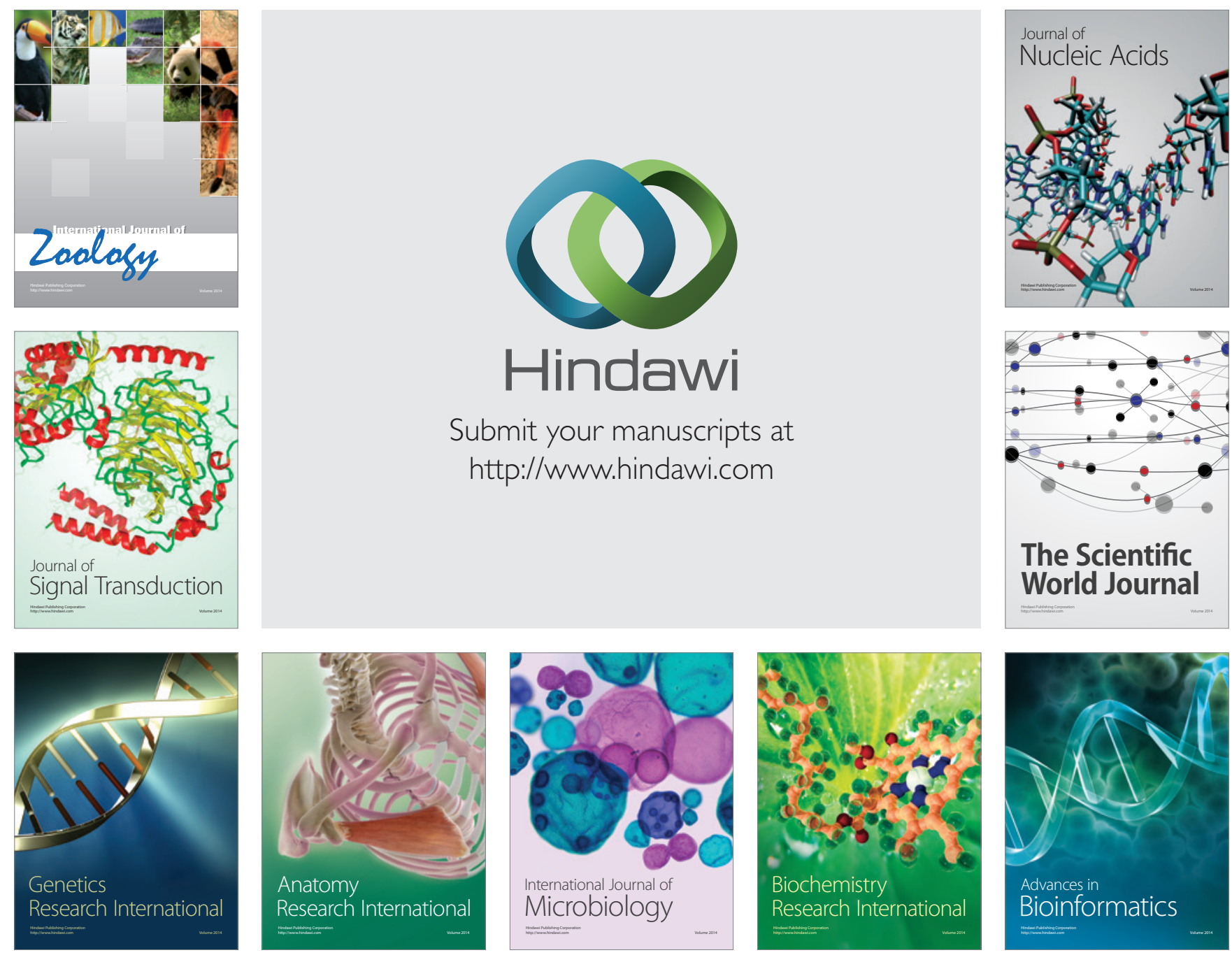

The Scientific World Journal
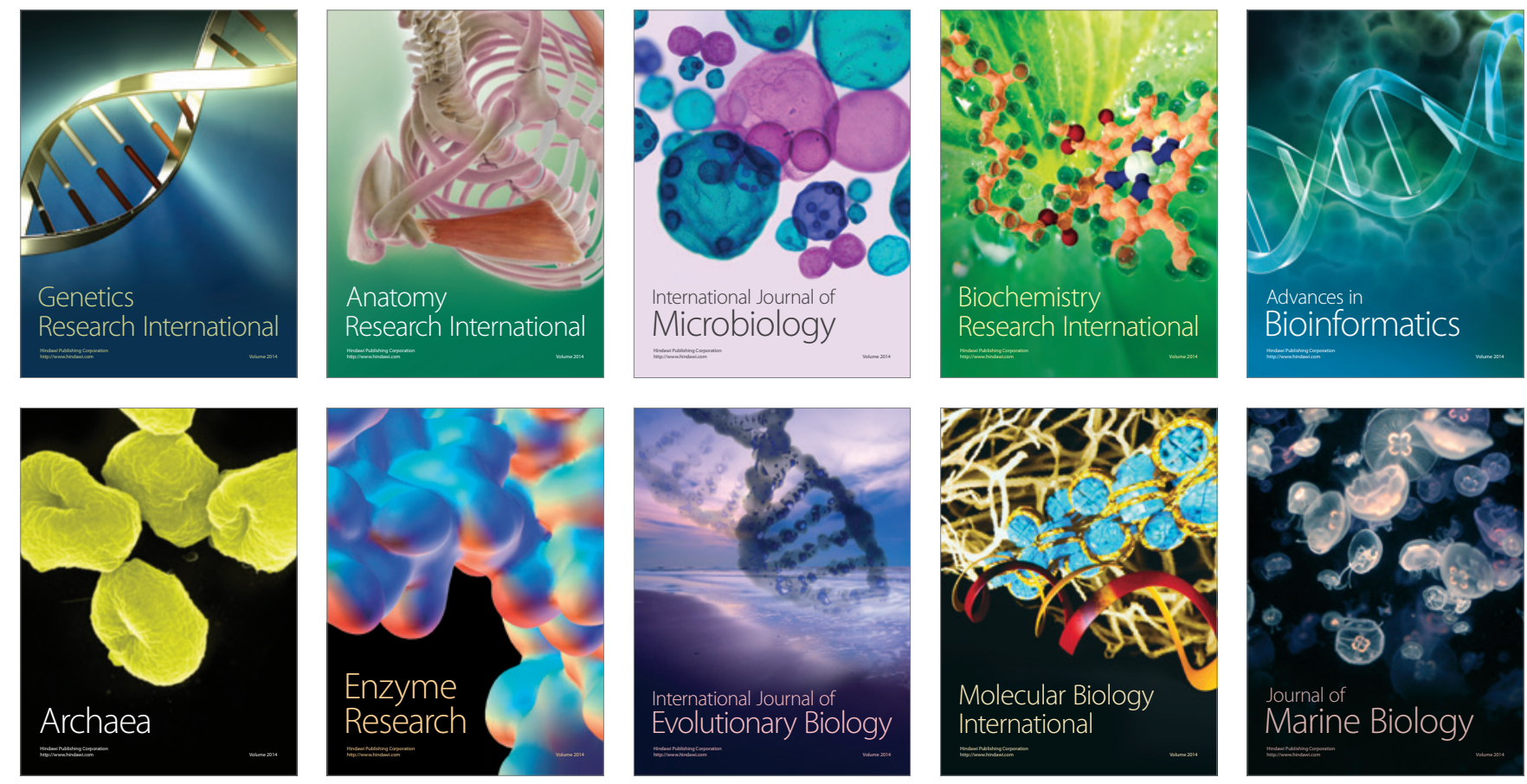